\title{
ANALISIS LAPORAN KEUANGAN
}

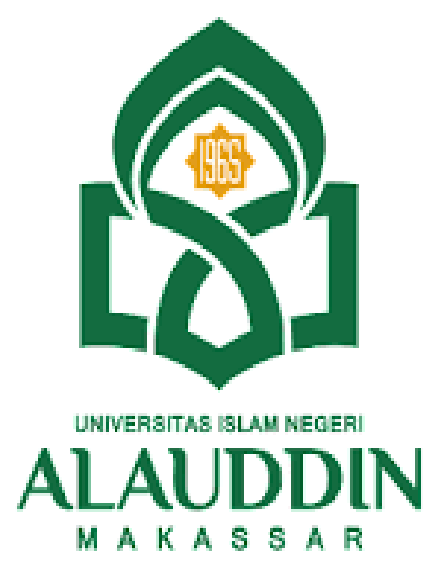

Makalah ini Disusun Untuk Memenuhi Tugas Pada Mata Kuliah Kewirausahaan

Oleh :

RANI RAHMAN ADY KAMPA

90500120094

Dosen Pengajar :

Dra. Hj. Nuraeni Gani , MM

PERBANKAN SYARIAH

FAKULTAS EKONOMI DAN BISNIS ISLAM

UIN ALAUDDIN MAKASSAR

TAHUN 2021 


\section{KATA PENGANTAR}

Puji syukur diucapkan kehadirat Allah SWT atas segala rahmat Nya sehingga makalah dengan judul “ Analisis Laporan Keuangan " dapat tersusun sampai dengan selesai. Saya sangat berharap semoga makalah ini dapat menambah pengetahuan dan pengalaman bagi pembaca. Bahkan saya berharap lebih jauh lagi agar makalah ini bisa pembaca praktekkan dalam kehidupan sehari-hari.

Bagi saya sebagai penyusun merasa bahwa masih banyak kekurangan dalam penyusunan makalah ini karena keterbatasan pengetahuan dan pengalaman saya. Untuk itu saya sangat mengharapkan kritik dan saran yang membangun dari pembaca demi kesempurnaan makalah ini.

Makassar, 27 Desember 2021

Penyusun 


\section{DAFTAR ISI}

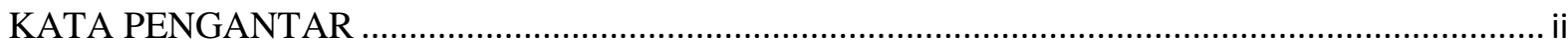

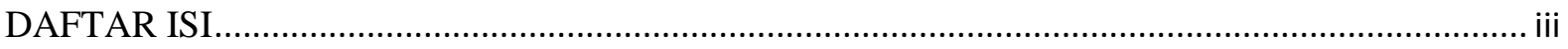

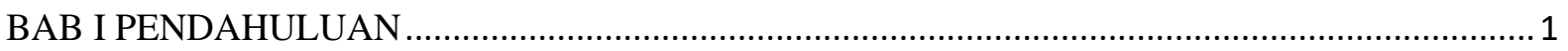

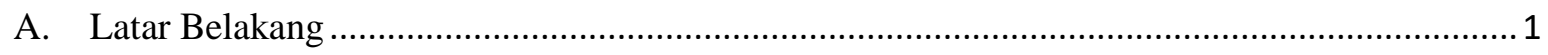

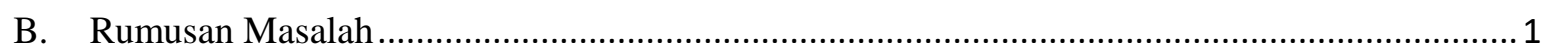

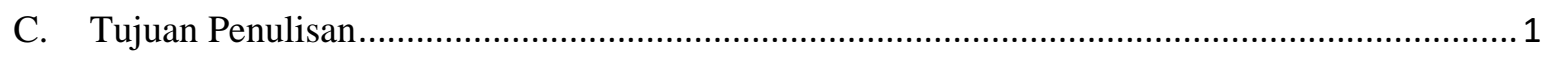

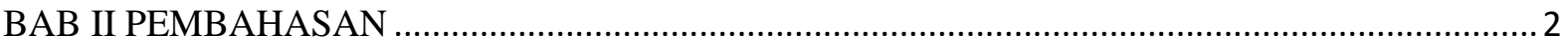

A. Pengertian Analisis Laporan Keuangan ........................................................................... 2

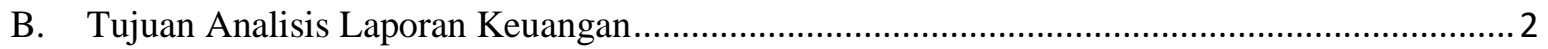

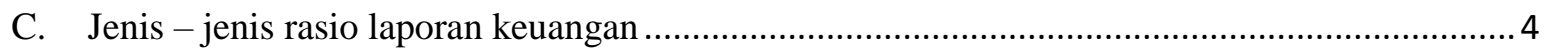

D. Langkah - langkah Analisis Laporan Keuangan .................................................................. 5

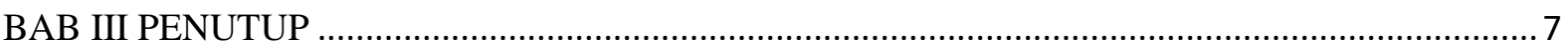

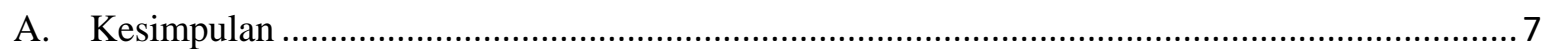

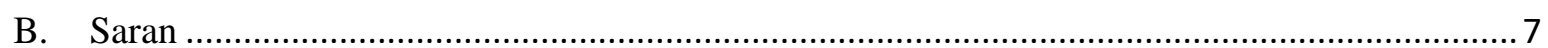

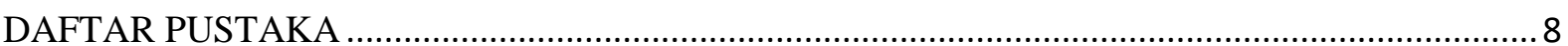




\section{BAB I \\ PENDAHULUAN}

\section{A. Latar Belakang}

Analisis laporan keuangan adalah suatu proses penelitian laporan keuangan beserta unsur-unsurnya yang bertujuan untuk mengevaluasi dan memprediksi kondisi keuangan perusahaan atau badan usaha dan juga mengevaluasi hasil-hasil yang telah dicapai perusahaan atau badan usaha pada masa lalu dan sekarang. Analisis terhadap laporan keuangan suatu perusahaan pada dasarnya karena ingin mengetahui tingkat keuntungan dan tingkat risiko dan tingkat kesehatan suatu perusahaan. Analisis terhadap laporan keuangan suatu perusahaan pada dasarnya karena ingin mengetahui tingkat keuntungan dan tingkat risiko dan tingkat kesehatan suatu perusahaan. Dalam melakukan analisis terhadap laporan keuangan tersebut diperlukan beberapa tolak ukur. Analisis yang biasa dipakai adalah rasio atau indeks yang merupakan perbandingan di antara data-data keuangan.

Analisis rasio keuangan merupakan alat utama yang dapat digunakan dalam melakukan analisis terhadap laporan keuangan. Melalui analisis rasio dapat dihasilkan pengukuran dalam bentuk rasio atau relatif dan bukan dalam angka yang absolut. Dengan demikian dapat mempermudah dalam melihat perubahanperubahan yang terjadi, apakah menunjukkan arah yang tetap, meningkat atau bahkan menurun. Faktor-faktor yang paling utama untuk mendapatkan perhatian analisis adalah tingkat likuiditas, profitabilitas atau rentabilitas, solvabilitas dan aktivitas.

\section{B. Rumusan Masalah}

1. Apa pengertian analisis laporan keuangan?

2. Bagaimana tujuan analisis laporan keuangan ?

3. Sebutkan jenis - jenis rasio laporan keuangan ?

4. Bagaimana langkah - langkah analisis laporan keuangan ?

\section{Tujuan Penulisan}

1. Untuk mengetahui analisis laporan keuangan

2. Untuk mengetahui tujuan analisis laporan keuangan

3. Untuk mengetahui jenis - jenis rasio laporan keuangan

4. Untuk mengetahui langkah - langkah analisis laporan keuangan 


\section{BAB II \\ PEMBAHASAN}

\section{A. Pengertian Analisis Laporan Keuangan}

Analisa Laporan Keuangan adalah suatu proses dalam rangka membantu menganalisis atau mengevaluasi keadaan keuangan perusahaan, hasil-hasil operasi perusahaan masa lalu dan masa depan, adapun tujuan analisis laporan keuangan adalah untuk menilai kinerja yang dicapai perusahaan selama ini dan mengestimasi kinerja perusahaan pada masa mendatang. Analisa laporan keuangan juga dapat melihat pertumbuhan kinerja keuangan dari tahun ke tahun. Analisis laporan keuangan proses peninjauan laporan keuangan suatu organisasi untuk mendapatkan pemahaman tentang situasi keuangan secara menyeluruh. Laporan keuangan biasanya mencakup neraca, laporan laba rugi, laporan arus kas dan laporan lain yang berkorelasi dengan proses keuangan bisnis. Analisis internal dilakukan oleh karyawan, eksekutif, lembaga pemerintah, atau individu lain yang memiliki akses ke catatan akuntansi internal perusahaan bisnis. Sebaliknya, analisis eksternal dilakukan oleh pihak luar yang memiliki akses ke laporan keuangan yang dipublikasikan. Pihak luar ini mungkin termasuk kreditur, investor, lembaga kredit, lembaga pemerintah atau masyarakat umum. Dari segi waktu, baik analisis jangka pendek atau jangka panjang dapat dilakukan. Sementara analisis jangka pendek mempertimbangkan kemampuan perusahaan untuk membayar utang jangka pendek, atau likuiditas, analisis jangka panjang mempertimbangkan kemampuan perusahaan untuk membayar utang jangka panjang, atau solvabilitas.

\section{B. Tujuan Analisis Laporan Keuangan}

Secara umum analisis laporan keuangan bertujuan untuk mengetahui tingkat efektif dan efisiensi kinerja keuangan perusahaan. Selain itu, analisis laporan keuangan juga digunakan sebagai tolak ukur bagi perusahaan untuk meningkatkan kinerja serta untuk membandingkan kinerja keuangan setiap periode akuntansi. Tujuan dan Manfaat Analisis Laporan Keuangan Menurut Para Ahli yaitu :

1. menurut Kasmir (2016: 68):

- Untuk mengetahui posisi keuangan perusahaan dalam satu periode tertentu, baik harta, kewajiban, modal, maupun hasil usaha yang telah dicapai untuk beberapa periode,

- Untuk mengetahui kelemahan-kelemahan apa saja yang menjadi kekurangan perusahaan,

- Untuk mengetahui kekuatan-kekuatan yang dimiliki,

- Untuk mengetahui langkah-langkah perbaikan apa saja yang perlu dilakukan ke deoan yang berkaitan dengan keungan perusahaan saat ini, 
- Untuk melakukan penilaian kinerja manajemen ke depan apakah perlu penyegaran atau tidak karena sudah dianggap berhasil atau gagal,

- Digunakan sebagai pembanding dengan perusahaan sejenis tentang hasil yang mereka capai.

2. menurut Sugiono dan Untung (2016:10) :

- Untuk memberikan informasi yang lebih mendalam terhadap laporan keuangan itu sendiri,

- Untuk mengungkapkan hal-hal yang bersifat tidak konsisten dalam hubungannya dengan suatu laporan keuangan,

- Dapat memberikan informasi yang diinginkan oleh para pengambil keputusan,

- Dapat digunakan untuk membandingkan dengan perusahaan lain atas dengan perusahaan lain secara industri,

- Untuk memahami situasi dan kondisi keuangan perusahaan,

- Dapat juga digunakan untuk memprediksi bagaimana keadaan perusahaan pada masa mendatang (proyeksi).

3. menurut (Hutauruk, 2017)

- Dapat menilai prestasi perusahaan.

- Dapat memproyeksi keuangan perusahaan.

- Dapat menilai kondisi keuangan masa lalu dan masa sekarang dari aspek waktu tertentu, yaitu posisi keuangan (aset, neraca dan modal), hasil usaha perusahaan (hasil dan biaya), likuiditas, solvabilitas, aktivitas serta rentabilitas atau profitabilitas.

- Melihat komposisi struktur keuangan (arus dana).

- Dapat membandingkan situasi perusahaan dengan perusahaan dengan periode sebelumnya atau dengan standar industri normal atau standar ideal.

- Dapat memahami situasi dan kondisi keuangan yang dialami perusahaan, baik posisi keuangan, hasil usaha, struktur keuangan dan sebagainya.

- Bisa juga memprediksi potensi apa yang mungkin dialami perusahaan di masa yang akan datang.

4. menurut (Kariyoto, 2017)

- Alat screening awal dalam memilih alternatif investasi atau merger.

- Alat forcasting mengenai kondisi dan kinerja keuangan di masa datang.

- Sebagai proses diagnostik terhadap masalah-masalah manajemen, operasi atau masalah lainnya.

- Alat evaluasi terhadap manajemen.

- Mengurangi dan mempersempit lingkup ketidakpastian yang tidak bisa dielakan pada setiap proses pengambilan keputusan. 
- Memberikan dasar yang layak dan sistematis dalam menggunakan pertimbanganpertimbangan.

\section{Jenis - jenis rasio laporan keuangan}

\section{Rasio Profitabilitas}

Rasio profitabilitas adalah rasio yang digunakan untuk mengukur dan melihat kemampuan perusahaan dalam menghasilkan sebuah keuntungan bagi perusahaan. Rasio profitabilitas dianggap sangat penting bagi kelangsungan perusahaan.karena urat nadi suatu perusahaan akan bergantung dari sejauh mana perusahaan bisa mendapatkan keuntungan. Manfaat rasio profitabilitas yaitu dapat mengetahui seberapa jauh perkembangan laba dari waktu ke waktu dalam perusahaan,dan dapat melihat perbandingan posisi laba perusahaan dari tahun sebelumnya dengan tahun sekarang. Rasio profitabilitas juga terbagi dari beberapa bagian yaitu :

a. Margin Laba Kotor (Gross Profit Margin)

b. Margin Laba Bersih (Net Profit Margin)

c. Margin Laba Operasi (Operating Profit Margin)

d. Rasio Pengembalian Aset (Return On Asset)

e. Rasio Pengembalian Modal sendiri (Return On Equity)

f. Penghasilan Per Saham (Earning Per Share)

\section{Rasio Likuiditas}

Rasio likuiditas adalah rasio yang mengukur kemampuan perusahaan dalam membayar atau melunasi kewajiban dalam skala jangka pendek dan harus segera dipenuhi. Manfaat rasio likuiditas yaitu dapat mempermudah pengguna atau staf keuangan untuk melakukan penarikan dana dan dapat mengantisipasi terjadinya keperluan dana pada saat situasi mendesak .

Rasio likuiditas juga mempunyai beberapa bagian,diantaranya :

- Rasio Lancar (Current Ratio)

- Rasio Cepat (Quick Ratio)

- Rasio Kas (Cash Ratio)

- Rasio Perputaran Kas (Cash Turnover Ratio)

\section{Rasio Solvabilitas}

Rasio solvabilitas adalah rasio yang dapat memperlihatkan atau menunjukan sejauh mana perusahaan mengendalikan kemampuan dalam melunasi semua kewajiban,baik dalam jangka panjang maupun dalam jangka pendek. Manfaat solvabilitas yaitu untuk mencari seberapa besar modal yang digunakan sebagai jaminan pinjaman (utang) dalam jangka panjang dan untuk melihat sejauh mana 
pengaruh pinjaman (utang) yang ditanggung perusahaan terhadap pengelolahan aktiva yang ada. Rasio solvabilitas terbagi atas beberapa bagian yaitu :

- Rasio Utang terhadap Aset (Debt To Asset Ratio)

- Rasio Utang terhadap Modal(Debt To Equity Ratio)

- Tangible Assets Debt Coverage

\section{Rasio Aktivitas}

Rasio aktivitas adalah rasio yang dapat digunakan untuk mengukur keefektifan atau ketetapan cara perusahaan dalam menggunakan aktiva-aktiva yang dimilikinya sehingga setiap akuntansi keuangan dapat berjalan dengan baik. Manfaat rasio aktivitas yaitu perusahaan bisa mengetahui perputaran pinjaman di setiap periodenya dan membandingkan setiap penjualan yang sudah dicapai dalam setiap perputaran modal. Rasio aktivitas terbagi atas beberapa bagian yaitu

1. Perputaran Aktiva (Total Assets Turn Over)

2. Rasio Perputaran Modal Kerja (Working Capital Turn Over)

3. Rasio Perputaran Aktiva Tetap (Fixed Assets Turnover)

4. Rasio Perputaran Persediaan (Inventory Turnover)

5. Rata-Rata Umur Piutang.

6. Perputaran Piutang

\section{Langkah - langkah Analisis Laporan Keuangan}

Menurut Prastowo (2011 : 58) terdapat berbagai langkah-langkah yang harus

ditempuh dalam menganalisis laporan keuangan. Adapun langkah-langkah yang harus dilakukan adalah :

1. Memahami latar belakang data keuangan perusahaan Mencakup pemahaman tentang bidang usaha perusahaan tersebut serta kebijakan akuntansi yang dianut dan diterapkan oleh perusahaan tersebut.

2. Memahami kondisi-kondisi yang berpengaruh pada perusahaan Mencakup informasi mengenai trend industri, dimana perusahaan beroperasi, perubahan teknologi, perubahan selera konsumen, perubahan faktor-faktor ekonomi dan perubahan yang terjadi di dalam perusahaan tersebut.

3. Mempelajari dan mereview laporan keuangan.

4. Menganalisis laporan keuangan.

Secara umum, metode yang digunakan untuk menganalisis laporan keuangan dapat diklasifikasikan menjadi dua yaitu (Prastowo, 2011:59) :

1. Metode analisis horizontal, dilakukan dengan cara membandingkan laporan keuangan dalam beberapa tahun (periode). Teknik analisis yang dimaksud antara lain teknik analisis perbandingan, analisis trend, analisis sumber dan penggunaan dana dan analisis laba kotor. 
2. Metode analisis vertikal, dilakukan dengan cara menganalisis laporan keuangan pada tahun tertentu yakni dengan kata lain, membandingkan satu pos dan pos lainnya pada laporan keuangan yang sama untuk tahun yang sama. Teknik analisis yang dimaksud adalah teknik presentase perkomponen, analisis rasio serta analisis impas. 


\section{BAB III}

\section{PENUTUP}

\section{A. Kesimpulan}

Analisa keuangan sangat penting untuk diterapkan dalam sistem suatu perusahaan.

Karena dengan menggunakan analisis keuangan ini perusahaan dapat mengetahui keuntungan dan kerugian yang dicapai perusahaan dalam suatu periode.

Analisa Laporan Keuangan adalah suatu proses penelitian laporan keuangan beserta unsurunsurnya yang bertujuan untuk mengevaluasi dan memprediksi kondisi keuangan perusahaan atau badan-badan usaha dan juga mengevaluasi hasil-hasil yang telah dicapai perusahaan atau badan usaha di masa lalu atau masa yang akan datang.

Analisa Rasio adalah yang menghubungkan perkiraan neraca dan laporan laba rugi terhadap satu dengan yang lainnya, memberikan gambaran tentang sejarah perusahaan dan penilaian terhadap suatu perusahaan tertentu.

\section{B. Saran}

Dalam penyusunan makalah ini, saya menyadari bahwa masih banyak kekurangan yang perlu ditambah dan diperbaiki. Untuk itu saya mengharapkan inspirasi dari para pembaca dalam hal membantu menyempurkan makalah ini. Untuk terakhir kalinya saya berharap agar dengan hadirnya makalah ini akan memberikan sebuah perubahan khususnya dunia pendidikan. 


\section{DAFTAR PUSTAKA}

-. (2018, Maret 6). Makalah Analisa Laporan Keuangan . (-, Produser) Dipetik Desember 28, 2021, dari Ilmuku: 2. https://retnosafitri77.blogspot.com/2018/03/makalah-analisa-laporankeuangan.html

-. (2021, Mei 2). -. Dipetik Desember 28, 2021, dari Harmony: 5.

https://www.harmony.co.id/blog/penjelasan-lengkap-analisis-rasio-keuangan-dan-jenisjenisnya

Media, A. (2020, Desember 22). Dipetik Desember 28, 2021, dari Creator Muda: https://creatormedia.my.id/langkah-dalam-melakukan-analisis-laporan-keuangan

Media, A. (21, Desember 2020). Dipetik Desember 28, 2021, dari creator media: 4. https://creatormedia.my.id/tujuan-dan-manfaat-analisis-laporan-keuangan-menurut-paraahli/kledo,

Setiyawan, A. (2016, November 8). Makalah Analisis Laporan Keuangan . Dipetik Desember 28, 2021, dari -: https://hendrosaputro15.blogspot.com/ 